FUTÓ Péter

\title{
A VÁLLALKOZÁSOKAT ÉRINTŐ JOGI SZABÁLYOZÁS HATÁSVIZSGÁLATA
}

\author{
I. rész
}

A szabályozás az állam és a vállalkozások kapcsolatának egyik lényeges aspektusa. A dolgozat a szabályozás minôségét javító kormányzati eszközöket és stratégiákat elemzi. A cikk elsố része áttekinti, hogy a fejlett országokban és a nemzetközi szervezetekben, így az Európai Unióban, ezen belül az EU-hoz újonnan csatlakozott országokban milyen hatásvizsgálati rendszerek fejlôdtek ki és ezek hogyan intézményesültek. A második részben a szerzó ismerteti a Világbank és az OECD azon kutatásait, melyek igazolták, hogy a vállalkozások szabályozási környezete, a cégeket terhelő adminisztratív teher mértéke igen erôteljesen befolyásolja az országok versenyképességét. Végül az írás bemutatja, hogy e fejlódés során az elmúlt két évtizedben milyen általános módszertani elvek és eszközök kristályosodtak ki a hatáselemzésben. ${ }^{1}$

\section{Kulcsszavak: vállalkozások, állami szabályozások, hatásvizsgálat}

A szabályozás az állam és a vállalkozások kapcsolatának egyik lényeges aspektusa. Ezért a jogszabályok szükségességének, méltányosságának és koherenciájának vizsgálata - a „regulációk megregulázása” - a korszerú államigazgatás egyik előfeltétele. A XIX. és a XX. század folyamán a legtöbb kormányzat alacsony minőségi kontroll mellett bocsátotta ki jogszabályait, így a közigazgatási rendszerek történetében viszonylag új gondolatnak számít, hogy a jogi szabályozás minősége értelmezhetô fogalom, és hogy ezt hatásvizsgálatok segítségével számszerúsíteni, sôt mérni is lehet.

A vállalatok profitorientált múködése összeütközésbe kerülhet a fogyasztók, az alkalmazottak vagy a környezet érdekeivel. Ezt a potenciális konfliktust minden kormányzatnak kezelnie kell, mégpedig úgy, hogy eközben ne korlátozza a vállalkozások hatékony múködését. Ezt a közfeladatot sokféleképpen lehet megoldani, és a modern bürokratikus államokban e megoldások egyike a vállalkozásokat érintố jogi szabályozás, mint a törvényhozás és a közigazgatás egyik fontos eszköze.

\section{A vállalkozások jogi környezetének minósége}

A vállalati szektor szabályozásának a leggyakoribb esetben az a célja, hogy nem kívánt események bekövetkezését hárítsa el az alábbi területeken: a cégek piac- ra lépése és versenye, a termékek forgalmazása, minősége és biztonsága, a termelés és a termékek környezeti hatásai, valamint a munkavállalás során megvalósuló kapcsolatok. A szabályok olyan pozitív normákat, értékeket fejeznek ki, amelyeket a szabályalkotó követendőnek tart, ilyen például a tisztességes verseny, a munkahelyi diszkrimináció tilalma vagy a környezet védelme. A szabályok segítségével a kormányzat vagy annak valamely adminisztratív szerve - büntetés terhe mellett - regisztrációs és engedélyezési kötelezettségeket, valamint korlátozásokat határoz meg a cégek egy meghatározott csoportja számára.

Minóségszemlélet. Az elmúlt két évtizedben a jogi szabályozás tartalmán, céljain túlmenően elótérbe került annak minősége is, különös tekintettel annak hatásaira. A vállalatokat érintő szabályoktól - mint minden kényszerító intézkedéstól - elvárható, hogy

- a közösség szintjén összesített hasznuk haladja meg azokat az összesített költségeket, amelyek a szabályozás hatálya alá esố vállalkozásoknál jelentkeznek,

- ne torzítsák el a piac múködését, ne vezessenek sem monopóliumokhoz, sem társadalmi igazságtalansághoz azzal, hogy egyes vállalkozási (és munkavállalói) csoportokat jobban sújtanak, mint másokat,

- mellékhatásaik legyenek csekélyek, nehogy olyan 
módosító, kiegészítő szabályokra legyen szükség, melyek már nem az eredeti problémát orvosolják, hanem a korábbi szabály okozta bajokat.

A szabályozás alternatívái. Azokat a veszélyeket, amelyek a fogyasztókat, alkalmazottakat és a környezetet a vállalkozások részéról fenyegetik, sok esetben nem jogi szabályozással célszerú elhárítani. A kormányzatok másként, piackonform beavatkozásokkal is befolyásolhatják az üzleti környezetet, így például támogatott programokkal, továbbá kedvezô kereteket teremthetnek az olyan intézmények érvényesüléséhez, mint amilyen az érdekegyeztetés, a vállalkozók közösségeinek bizonyos keretek között megvalósuló önszabályozása, a vitás ügyek választott testületek segítségével megvalósuló egyeztetése, a tulajdonjog, a szavatosság és a biztosítás.

Hatásvizsgálatok. Az elmúlt két évtizedben a fejlett országokban szabályozási reformok sorát kezdeményezték, amelyek tervezéséhez társadalmi jelzôszámokra volt szükség. A kormányzatok úgy „ex ante” mint „ex post” megközelítéssel élnek a jogszabályok és javaslatok hatásainak mérése során. A hatásvizsgálatok által szolgáltatott számszerú mutatók sok esetben hozzájárultak a közéleti szereplő́k szemléletének formálásához. Az intézkedések hatásairól kapott viszszajelzések fontos szerepet töltenek be a koncepciók kialakításában és azok folyamatos finomhangolásában. Az adminisztratív terhek mérése lehetôvé teszi, hogy a kormányzatok „benchmarking” jellegú etalonokat fogalmazhassanak meg a szabályozás minőségével kapcsolatban.

Míg az egyes kormányszervek szintjén sok ilyen kezdeményezés figyelhetố meg, addig viszonylagos hiány van az olyan mérési technikákban, és azok alkalmazásában, melyek eredményeképpen a kormányzatok átfogó, tárcákon átívelő képet kaphatnak a vállalkozásokat sújtó adminisztratív terhekról.

A hatások mérésének technikái még nem tekinthetőek éretteknek, és a kormányzatoknak intenzív tapasztalatcserére van szükségük a legjobb gyakorlatok egybevetése, kiérlelése és terjesztése céljából. A kormányzatok és a nemzetközi szervezetek berkeiben meglehetôsen eltérő szemléletú és megközelítésú hatásvizsgálati kultúrák honosodtak meg. Ezek egységesítésének korlátot szab, hogy a kormányzati filozófiák heterogének, a szabályozás hasznairól, szükségességérôl kialakult nézetek ideológiai elemekkel vegyülnek, a legtöbb országban ragaszkodnak az intézményi környezet tradicionális, bevált megoldásaihoz. Az általánosan használható megoldás elterjedését fékezi, hogy a hatásvizsgálatok során használt adatbázisok is igen sokfélék.

\section{Az Európai Unió által kibocsátott szabályok vizsgálata}

Az Európai Unió adminisztratív szervezeteinek fớ tevékenysége arra irányul, hogy kifejlessze és a földrészen elterjessze a jó kormányzás (good governance) megfelelố módszereit. A kis- és középvállalkozások fejlesztésének uniós szintû́ politikájában régóta elfogadott felismerés, hogy KKV-k viszonylagos gyengeségének és sebezhetôségének egyik legfontosabb oka az egyre bonyolultabb törvényi és adminisztratív környezet. ${ }^{2} \mathrm{Az}$ unió versenyképessége előtt álló kihívások felismerése tovább erósítette azt a politikai szándékot, hogy központilag támogatott és összehangolt eszközökkel javítsák a szabályozás minőségét. ${ }^{3}$ E célt elsốsorban az alábbi három módon intézményesítették: szabályozási hatásvizsgálatokkal, a jogszabályok egyszerúsítése útján és az érdekcsoportokkal való konzultáció segítségével.

A szabályozási hatásvizsgálatok egyik szerepe éppen az, hogy tisztázza: szükség van-e egyáltalán az elő́terjesztett szabályozásra? Mert az „Acquis Communautaire" néven ismert, folyamatosan bővülő uniós jogszabálygyújjtemény csak az egyik eszköze a tagállamok úgynevezett „európaizációjának”. Emellett nagy szerepe van a támogatáspolitikának és az úgynevezett „,nyílt koordinációs módszereknek” (open methods of co-ordination). Ez utóbbi stratégia lényege, hogy konzultációs fórumokon összegyuujtik az úgynevezett jó kormányzati és vállalatii ${ }^{4}$ eljárásokat (best practices, good practices), ezeket „,benchmark” formájában felmutatják és elterjesztik, majd - a támogatáspolitika eszközeivel is ösztönözve - folyamatosan figyelemmel kísérik, hogy a tagországokban bekövetkezik-e a kívánt konvergencia. ${ }^{5}$

A szabályozási hatásvizsgálat, mint a jobb szabályozás elérésének eszköze, az elmúlt két évtizedben gyorsan terjedt az Európai Unió intézményeiben és a tagállamokban is. ${ }^{6}$ A nyolcvanas évek óta a közösségi törvényhozás hatásainak vizsgálata folyamatosnak tekinthetô (Regulatory Impact Assessment vagy Business Impact Assessment, Fiche d'Impact). Ennek keretében a szabálytervezeteket rendszeresen ún. szubszidiaritási és arányossági teszteknek vetik alá. Rendszeres formális és informális érdekegyeztetési tanácskozásokon vizsgálják meg: nem rónak-e túl nagy terhet a szabályozók a szabályozottakra. Már a 90-es évek során több száz, tervezett direktíva hatásainak vizsgálata jelent meg papíralapú kiadványokban és késốbb az interneten is. ${ }^{7}$

2001-ig az Európai Unióban az alábbi szempontokból vizsgálták meg a kibocsátott szabályozások egy részhalmazát: 
- költségvetési értékelés. Ez a hatásvizsgálati forma az intézkedéseknek az Unió költségvetésére gyakorolt hatását vizsgálja.

- környezeti hatásvizsgálatok. E hatásvizsgálatok célja, hogy feltárják az Unió intézkedéseinek a természeti környezetre gyakorolt hatását. Ennek módszertanát a Környezetvédelmi igazgatóság fektette le, de a környezetvédelmi hatásvizsgálatokat az EU valamennyi más fóigazgatóságnak meg kell valósítania.

- vállalkozási hatásvizsgálatok (business impact assessments). E hatásvizsgálatok célja, hogy az EU Bizottsága által előterjesztett jogszabályok az Unió vállalkozásait csak az ésszerúségnek megfelelő mértékben terheljék. E vizsgálatok módszertanának gazdája a Vállalkozási Fốigazgatóság, de valamennyi olyan foóigazgatóságnak meg kell valósítani őket, amelyek vállalkozásokat is érintő jogszabályokat bocsátanak ki, vagy készítenek elő.

Az ezredforduló környékén az Európai Unióban erősödött a formalizált, intézményesedett hatásvizsgálati rendszerek iránti igény. ${ }^{8}$ A múködő hatásvizsgálati rendszerekról kialakult az a vélemény, hogy azok eleinte betöltötték funkcióikat, de egymással kevéssé álltak kapcsolatban, és hamar megmerevedtek, elbürokratizálódtak. A rendszer bírálói hangoztatták, hogy a hatásvizsgálatokat egyszerúsíteni és egységesíteni kell. Javasolták, hogy a hatásvizsgálatokat kötelezó jelleggel terjesszék ki az unió valamennyi fontos szabályozási kezdeményezésére, ötévenként vizsgáljanak újra minden lényeges jogszabályt, és a vizsgálatok térjenek ki a társadalmi hatásokra is.

A terjedelmi jellegú követelményekkel párhuzamosan erôsödtek az elemzések minősége iránt támasztott igények. A viták során elhangzott, hogy a hatásvizsgálatok elvégzése ne legyen önmagában való cél, hanem azok legyenek a politikai folyamat szerves alkotóelemei, csökkentsék a szabályozási kudarcok kockázatát, és tegyék áttekinthetôvé azt a szabályozási reformfolyamatot, melynek célja az úgynevezett „good governance”, tehát a jó kormányzás. Hosszabb távon egy egységes Regulatory Management szabályozási menedzsment politikát kell kialakítani, melynek része a kötelezô konzultáció az üzleti érdekcsoportokkal.

A bírálatok a 2000-ben meghirdetett lisszaboni stratégia nyomán felerősödtek. Ez a stratégia nagy hangsúlyt helyez a versenyképességre, így érthetó, hogy ennek jegyében az EU több magas szintú fóruma sürgette az Európai Bizottságot, hogy tüzetesebben fog- lalkozzon azzal, hogyan lehet a versenyképesség és az adminisztratív terhek kérdéseit számításba venni a hatásvizsgálat során.

Fontossá vált, hogy az unióban is dinamikusan csökkenjenek a vállalkozásokat sújtó szabálykövetési költségek (compliance costs). Ha e költségek magasak maradnak, akkor nehezítik a termelékenység növelését és magát a gazdasági növekedést, elszívják a vállalkozások energiáit és erôforrásait, és magasabb árak formájában gyakran áthárulnak a fogyasztóra, beavatkozva ezzel a jövedelemelosztásba, és méltányossági kérdéseket is felvetnek. E költségek magas színvonala mérsékeli a nemzetközi versenyképességet is, különösen, ha a tengerentúli vállalkozások alacsonyabb szabálykövetési költségek mellett operálhatnak. Ha a szabálykövetési költségek magasak, akkor ez alááshatja a szabályozás eredményességét is, hiszen a magas szabálykövetési költségek a szabályozás megszegésére ösztönöznek, és ezért további versenyhátrányba kerülnek a szabályozásnak megfelelő vállalatok.

2002-ben azután - számos kísérleti hatásvizsgálati projekt értékelése nyomán - az Európai Unió új hatásvizsgálati módszert vezetett be. ${ }^{9}$ Az EU-bizottságának különböző fôigazgatóságai most már egységes keret és módszer szerint kötelesek elvégezni a hatásvizsgálatokat. A korábbi rendszerhez képest újdonságnak számít, hogy egységes rendszerben vizsgálják valamennyi, a szabályozás által érintett érdekcsoport szempontjainak érvényesülését, és az értékelésekben mind gazdasági, mind pedig társadalmi és környezeti szempontokat is érvényesíteni kell. Az új hatásvizsgálati szabályzat szerint először a foóbb javaslatok előzetes hatásvizsgálatát végzik el, és csak akkor végeztetnek el kibővített vizsgálatot, ha arra külön döntés születik az elôzetes eredmények alapján.

A szakértők azonban a hatásvizsgálat reformját további folyamatos kritikával illették. 2003-ban az EU szakmai fórumai ${ }^{10}$ ausztrál mintát követve ${ }^{11}$ azt javasolták, hogy a kormányzatok ne csak ez egyes jogszabályok szintjén végezzenek hatásvizsgálatot, hanem értékeljék egy-egy teljes szabályozási terület (ilyen pl. a környezetvédelem vagy a vállalkozásalapítás), sok esetben egy-egy tárca szabályozási munkájának egészét. A tárcaszintú értékelés alapuljon számos, a tárca hatáskörébe tartozó jogszabály hatásvizsgálatán, és készüljenek indikátorok, melyek a szabályozási környezetet értékelik. Példák az így származtatható indikátorokra:

- Azon szabályozások aránya egy adott szabályozási területen, amelyekre a RIA (szabályozási hatásvizsgálat, Regulatory Impact Assessment) kellő́képpen kimutatja azt, hogy ezek a közösség számára nettó haszonnal járnak. 
- Azon szabályozások aránya egy adott szabályozási területen, amelyek esetében a RIA megfelelőképpen indokolja a betartásukkal járó költségeket a vállalatok számára.

- Azon szabályozások aránya egy adott szabályozási területen, amelyek tartalmaznak konzultációs nyilatkozatot, azaz olyan függeléket, amely leírja, hogy az érdekcsoportokkal való egyeztetésnek milyen tanulságai voltak.

- Azon szabályozó ügynökségek vagy hivatalok aránya egy adott szabályozási területen, amelyek kommunikációs stratégiával rendelkeznek a szabályozásra, a formális érdekegyeztető folyamatra vonatkozóan.

Ez a megközelítés egyelőre nem valósult meg.

2004 januárjában Írország, Hollandia, Luxemburg, Nagy-Britannia, Ausztria és Finnország pénzügyminiszterei újabb javaslatot tettek az Európai Unió szabályozási rendszerének reformjára. ${ }^{12}$ Ebben szorgalmazták egy közös európai módszertan kidolgozását, amely alkalmas arra, hogy a szabályozások által okozott adminisztratív terheket mérje. Javasolták, hogy 2005 után az EU végezze el valamennyi új direktíva (EU-irányelv) hatásvizsgálatát a közös jóváhagyott módszertannal, és hogy rendszeresen, intézményesített módon egyszerǘsítsék a jogi szabályozást az Európai Unió szintjén és annak tagállamaiban. Hangsúlyozták, hogy a hatásvizsgálati tevékenységnek folyamatosnak kell lennie, szorosan össze kell kapcsolni a versenyképességet fokozó intézkedésekkel, és hogy e tevékenységet be kell ágyazni az üzleti érdekcsoportokkal való konzultáció rendszerébe. A szabályozás minőségét minőségellenórzési módszerekkel kell folyamatosan szinten tartani, és ezt az ellenôrzést külsố - tehát az államigazgatástól független - szakértóknek kell megvalósítani.

2006-ban az Európai Bizottság nyilatkozatban vállalta, hogy 2012-ig a tagállamokkal közösen 25\%-kal csökkentené a vállalatok adminisztratív terheit, ami hatásvizsgálati számítások szerint várhatóan 1,5\%-os GDP-növekedést, valamint 150 milliárd eurót elérô növekedést és új munkahelyeket teremtő beruházást eredményezhet. ${ }^{13}$

A szabálykövetési költségek kiszámítására számos tudományos és tanácsadó intézmény szakosodott. A RIA egyes munkafolyamatait a közszférából a magánszférába helyezték ki, és ez a legtöbbször új módszereket, többletismereteket hozott a vizsgálatba. Az EU Bizottság Vállalkozási Fớigazgatósága által külsô tanácsadó cégekhez kiszervezett hatásvizsgálatok általában 9-12 hónap alatt készülnek el, és 50.000-400.000 euróig terjedő összegbe kerülnek.
A rendszer azonban továbbra sem tekinthetô stabilnak. 2006-ban az EU Bizottságának megbízásából független bizottság értékelte az új hatásvizsgálati rendszer bevezetése, azaz a 2002 óta elvégzett hatásvizsgálatok, a RIA-k tapasztalatait. A feltárt fóbb hiányosságok a következók:

- nehéz adatokat szerezni a RIA elkészítéséhez,

- a közvetett hatások és a nem kézzelfogható hasznok nehezen számszerúsíthetók,

- a RIA igényes elkészítéséhez gyakran hiányzik a szakértelem és hiányoznak az erőforrások,

- a különböző policy opciókat nem megfelelően választják ki, és nem reálisan értékelik,

- a RIA folyamata gyakran nem eléggé átlátható,

- sokszor nem jutnak el az érdekcsoportokkal való konzultációkig,

- a politika és annak megvalósításáért felelős bürokrácia nincs kellóképpen összehangolva,

- a folyamatban lévő RIA-n nem végeznek minóségellenőrzést,

- gyakran csak a döntéshozatali folyamat kései szakaszaiban kerül sor RIA-ra.

A hatásvizsgálatok érvényesülésének folyamatát lassítja, hogy 2006-ban még mindig nem jött létre az Európai Unió régóta tervezett központosított hatásvizsgálati intézménye, és a tagállamok többségében nincs kijelölt és megfelelő jogosítványokkal ellátott hatásvizsgálati szerv. ${ }^{14}$

\section{A jogi szabályozás hatásának mérése egyes nyugat-európai országokban}

Az uniós tagállamok nagy hangsúlyt fektetnek a kormányzati szervekkel, valamint a szabályozás érintettjeivel folytatandó párbeszédre, az értékelés strukturáltságára és folyamatjellegére. Több EU-tagországban publikáltak szabályozási hatásvizsgálat készítéséról szóló útmutatókat ${ }^{15}$, ezeken belül speciálisan a kisvállalkozásokra gyakorolt hatások mérési útmutatóit. A tagországok rendszeresen tartanak hatásvizsgálati képzéseket köztisztviselốk számára.

Az útmutatók kiemelik, hogy az elemzések hitelessége azon múlik, hogy sikerült-e megbízható adatokat szerezni, ezek alapján robusztus elemzést végezni, valamint számszerúsíthető, laikusok számára is érthető eredményeket előállítani. Ezért kívánatosnak tartják az alapos módszertant és a költségek és hasznok lehetőleg pénzegységben történő számszerúsítését. Amennyiben a hasznokat nem lehet pénzben kifejezni, akkor is kívánatos a számszerúsítés, pl. a megmentett életek várható száma, változás a károsanyag-kibocsátás szintjében stb. 
Ha erre sincs mód, akkor legalább utalni kell a szabályozás hatásaként megjelenó költségek és hasznok fóbb csoportjaira.

Egyesült Királyság. Európában Nagy-Britannia jár elöl a kormányzati szabályozás minőségének folyamatos, intézményesített ellenôrzésében. 1988 óta készítenek szabályozási hatásvizsgálatokat (RIA, Regulatory Impact Assessment). A kormányzat szerint a RIA-k a szabályozás javításának („,better regulation”) legfontosabb eszközei. A hatásvizsgálatok egyik feladata, hogy kimutassák, mikor felesleges egy szabályozás, és mikor van arra valóban szükség. Hatásvizsgálatok nemcsak az angol, hanem az uniós jogszabályokra is készülnek. Hatásvizsgálat tárgya egyaránt lehet a közszférát, a magánszférát (pl. a kisvállalkozásokat), vagy akár a nem kormányzati szférát érintő szabályozás.

Kezdetben a RIA-k költség-haszon elemzések voltak, amelyek a szabályozási javaslatot elemezték, különös tekintettel a kis- és középvállalkozásokra ${ }^{16}$ és a versenyre. Azóta ez kiterjedt az egészségügyi hatásokra, a fenntartható fejlődésre is, valamint a különböző bơrszínú emberek esélyegyenlőségének vizsgálatára, továbbá a vidéki térségekre való hatást is megvizsgálják. A brit hatásvizsgálatoknak kiemelt szerepük van a deregulációs munkában, tehát a felesleges jogszabályok azonosításában és ezek hatálytalanításában. A RIA-ba fektetett erófeszítéseknek arányosnak kell lenni a javaslatok valószínú hatásával. Csekély várható hatású szabályozásra nem kell RIA-t készíteni.

A RIA-knak különös figyelemmel kell kísérniük az ún. szabálykövetési költségeket (compliance costs). A hatásvizsgálatokért felelős kormányhivatal folyamatosan fejleszti a RIA-khoz szükséges módszertani eszköztárat. Célja, hogy világosabbá és konzisztensebbé tegye a RIA-kat.

2005-ben a brit kormány különbözô szervezetei körülbelül 200 RIA-t készítettek különböző tervezett jogszabályok hatásainak vizsgálatára. ${ }^{17}$ A munkát az úgynevezett Better Regulation Executive (BRE) hangolja össze, mely a Miniszterelnöki Hivatal részét alkotja. Feladata, hogy a kormányzat szabályozási politikájának minőségét felügyelje, az úgynevezett jobb szabályozás (,,better regulation”) politikát múködtesse.

A minisztériumok általában külső szakértóket, így közgazdászokat és statisztikusokat alkalmaznak a RIA$\mathrm{k}$ elkészítéséhez. A RIA-k készítésével kapcsolatos információkat minisztériumi intraneteken osztják meg. A RIA-k végsố formáját a jogszabályt előterjesztô tárca minisztere írja alá, aki ezzel kijelenti, hogy a szabályozás haszna igazolja annak költségeit. Ezt az állítást a RIA kvantitatív és kvalitatív technikáinak segítségével igazolják, illetve jelzik az esetleges bizonytalanságokat.
Néhány példa a brit Kereskedelmi és Ipari Minisztérium által gondozott jogszabályokra, amelyekre a közelmúltban RIA készült:

- a munkaügyi bíróságokra vonatkozó jogszabályok módosítása,

- Munkaügyi Kapcsolatok Törvény 2004,

- a nemzeti minimálbér növelése és

- más jogszabályok.

A brit hatásvizsgálati politikát a kormányzat független szakértőkkel rendszeresen értékelteti. 2006-ban a National Audit Office (Állami Számvevôszék) értékelése négy minisztérium munkáját ölelte fel, ezek a Kultúra-, Média- és Sportminisztérium (DCMS, Department for Culture, Media and Sport), a Kereskedelmi és Ipari Minisztérium (DTI, Department for Trade and Industry), a Belügyminisztérium (Home Office) és a Közlekedési Minisztérium (DfT, Department for Transport).

Az értékelés során bőséges mintát vettek az elkészült szabályozási hatásvizsgálatokból, és különböző teszteknek vetették alá azokat. Az értékelók az alábbi szempontokból vizsgálták az általuk áttekintett RIA-kat:

- célirányosság (az összes opció áttekintése, a célok világossága, az intervenció racionális volta),

- megfelelnek-e a Better Regulation Unit által kibocsátott módszertani irányelveknek,

- használnak-e új innovatív technikákat,

- alkalmaznak-e kvantitatív és kvalitatív elemzéseket, köztük költség-haszon elemzéseket és érzékenységvizsgálatokat,

- milyen mélységben vizsgálják meg a szabályozás és a szabálykövetés valódi hatásait,

- követik-e a szabályozás utóéletét is úgynevezett monitoring, valamint ex-post értékelés keretében,

- vizsgálják-e a szabályozás versenytorzító vagy versenybefolyásoló hatását,

- szerepet kapott-e bennük a konzultáció, amely a jogszabály által szabályozott érdekcsoportok (stakeholder) nézeteit hivatott összegyújiteni.

A brit Számvevôszék (National Audit Office) az egyes minisztériumokat az alábbi szempontokból értékelte:

- mennyire mély ott a hatásvizsgálat kultúrája, mennyire proaktív a szervezet (mennyivel előzi meg a hatásvizsgálat a jogszabály tervezett hatályba lépését),

- mennyire mélyen integrálódik a politikai folyamatba a hatásvizsgálat,

- mennyire helyezik elótérbe a gazdasági hatások feltárását. 
Az értékelő́k gyengének minősítették az olyan RIAkat, amelyek csak formálisan teljesítik a RIA-kra vonatkozó követelményeket, viszont megdicsérték azokat, amelyeket teljes mértékben integráltak a döntéshozatali folyamatba. A két véglet között helyezkednek el azok a RIA-k, amelyek hasznosak, de csupán azért, mert informatív szereppel bírnak.

A National Audit Office értékelése szerint a hatásvizsgálatok minősége kiábrándító. Bár a hatásvizsgálatok elkészítésének kultúrája Nagy-Britanniában már igen fejlettnek tekinthetô, a bennük foglalt elemzések sokszor nem eléggé meggyőzőek, prezentációjuk sokszor nem eléggé világos. Ezért a RIA-k csak egyes esetekben használhatók arra, hogy a szabályozás szükségességét megkérdójelezzék. Emellett azonban a legtöbb RIA-nak nagyon értékes kommunikációs szerepe van, amely hozzájárul a minisztériumi döntéshozatal áttekinthetôségének fokozásához. A RIA-kat gyakran túl későn valósítják meg, és ezek gyakran nincsenek összhangban a politikai szándékokkal. A RIA-knak jobban kell koncentrálni arra, hogy valóban gazdasági hatásvizsgálatok valósuljanak meg, és megállapításaik ne pusztán adminisztratív, államigazgatási jellegúek legyenek. Jobban kell integrálni ốket a döntéshozatali folyamatokba, világosabban fel kell tárniuk a politika elốtt álló alternatívákat, sokkal jobban kellene szakértői munkára támaszkodniuk, és kezdeményezóbb módon kellene a lehetôségeket az államigazgatási dolgozók számára feltárniuk.

Hollandiában 1985 óta végeznek szabályozási hatásvizsgálatokat, úgy törvényekre, mint rendeletekre vonatkozóan. A valamennyi minisztériumban végzett hatásvizsgálat összehangolása 1994-ig az igazságügyi tárca feladata volt, majd ezután - a versenyképesség szempontjának elôtérbe kerülésével - a gazdasági tárca hatáskörébe tartozik ez a feladat. Az alkalmazott módszertanra jellemző a kérdéslisták (checklist) rugalmas használata. ${ }^{18}$

A Hollandiában meghonosodott MISTRAL módszer csak a szabálykövetési költségeket tárta fel, a szabályozások kedvezó hatásával nem foglalkozott. 1993-tól az ezredfordulóig alkalmazták, és ekkor váltotta ezt fel az SCM (Standard Cost Model). A MISTRAL módszer kimutatta, hogy Hollandiában az 1993-at követố öt év alatt pénzben kifejezve egynegyedével nőttek a kisvállalkozásokra nehezedô adminisztratív terhek. E mérési eredményekre alapozva fogalmazta meg a kormányzat azokat az intézkedéseket, amelyek

- korlátozták az egyes kormányszervek számára, hogy ugyanazokat az adatokat többször is elkérjék a vállalkozásoktól,

- egységesítették a kormányszervek által használt adatszótárakat,
- indokláshoz kötötték a kormányszervek által megfogalmazott adatigényléseket és

- megtiltották az adatszolgáltatásra kötelezett ügyfelek indokolatlan sürgetését.

A MISTRAL adatgyújtési módszere azon alapul, hogy reprezentatív mintát vesznek a vállalkozások és a hatóság közötti interakciókból, történjen az papíron, telefonon, személyesen vagy elektronikus úton. Ezeket az interakciókat azután idô- és erőforrás-igényességük szerint összesítik és pénzben kifejezik. A terhekbe a szabályozások által kikényszerített, a vállalkozásokat sújtó tanácsadói, könyvelői és utánajárási költségeket is beleszámítják.

Belgiumban egy 1998-as törvény létrehozott egy adminisztratív egyszerúsítési kormányhivatalt (ASA). Ez a kormányszerv évente összeállítja az összes létezô közigazgatási eljárás lépéseit, és méri azok idôigényességét, komplexitását. Az így felmerülő terheket az adott közigazgatási eljárás által érintett vállalkozások és háztartások számával súlyozva összegzik, és ebból összesített adminisztratív teher indexet számítanak.

Svájcban 1999 óta a Gazdasági Államtitkárság (Staatssekretariat für Wirtschaft) a törvények és rendeletek minden lényeges módosítása előtt köteles elvégezni egy úgynevezett KKV-hatásvizsgálatot (KMUVerträglichkeitstest). Ennek keretében a vállalkozások egy csoportját megkérdezik a rendelkezés várható hatásairól. ${ }^{19}$

Németországban a szövetségi minisztériumok számára 2000-ben egységes ügyviteli rendet vezettek be, amely kötelezóen előírja, hogy a törvények és rendeletek előzetes indoklásához hatásbecslést (Gesetzesfolgenabschätzung, GFA) kell végezni. ${ }^{20}$ A kezdeményezés azonban a gyakorlatban nem vált be, fóként mert a rendelkezésre bocsátott módszertant a minisztériumi apparátusok túlságosan bonyolultnak ítélték. Bár a hatásvizsgálat jogintézménye a tartományi minisztériumok jelentős részében is megjelent, az országban összességében csak néhány szabályozási hatásvizsgálati mintaprojekt született.

Svédországban először az 1998-as SimpLex törvény mondta ki, hogy a kormányhivatalok kötelesek hatásvizsgálatot készíteni minden új jogszabály és módosítás előterjesztésekor. A törvényhez mellékelt módszertan alapján a szabályozó intézménynek ilyen esetben 12 kérdésre kell válaszolni, melyek többsége a KKV-kre gyakorolt várható hatást firtatja. Az ország központi ipari és kereskedelmi kamarája 2002 óta éves jelentésekben értékeli a hatásvizsgálati tevékenységet, 
és ennek kapcsán a vállalatokat érintô szabályozás egészét. A kamara 2006-os jelentése kemény bírálatban részesíti a kormányzatot. ${ }^{21} \mathrm{Az}$ ambiciózus jogszabályegyszerúsítési tervek ellenére nőttek az adminisztratív terhek, és tartósan alacsony a szabályozási hatásvizsgálatok általános minősége.

\section{Jogharmonizációs hatásvizsgálatok Magyarországon}

Az 1990-es évek közepétól az Európai Unióhoz csatlakozni kívánó közép- és kelet-európai országok mindegyikében kiemelt jogalkotási feladat volt, hogy az unió joganyagát, az úgynevezett „Acquis Communautaire” nevú jogszabálygyújteményt átültessék nemzeti jogrendszereikbe. Ebból a célból ezekben az országokban sorra jogszabály-honosítási, más szóval jogharmonizációs terveket készítettek, melyek politikaterületenként haladva sorra vették a releváns uniós irányelveket és döntéseket, és előírták azok honosításának módját, felelôseit és annak ütemét. Magyarországon a hároméves jogharmonizációs terv a kormány 2403/1995. számú határozatában öltött testet.

A harmonizációs munkát a legtöbb csatlakozó országban - így Magyarországon - hatásvizsgálatokkal készítették elő. Ezeknek a hatásvizsgálati eljárásoknak nem alakult ki az egységes módszertana, múfaja, de ezek az alkalmazott kutatások többnyire az európai, 1986 óta múködő úgynevezett ,fiche d'impact” (jelentése: hatásvizsgálati dosszié) nevú eljárásából, valamint a brit kormány 1988 óta múködtetett „Better Regulation” központjának ajánlásaiból merítettek ötleteket.

E hatásvizsgálatok közös célja és tulajdonsága volt, hogy tudományos szigorral jelölték ki egy érdekegyeztetési folyamat kereteit. Ebben a konzultációban a szabályozást elrendelő, felülvizsgáló, módosítani kívánó kormányzatok két oldalról is nyomásnak voltak kitéve: az egyik irányból a szabályozást elszenvedô szervezetek és érdekképviseleteik részéról, másfelól pedig a jogharmonizációt szorgalmazó, annak megvalósulását ellenőrző uniós tárgyalófelek részéról.

Magyarországon a jogharmonizáció elôkészítésével, lebonyolításával megbízott minisztériumok csak korlátozott összeggel támogathatták ezt a kutatómunkát. Ezért a hatásvizsgálathoz alapvetően kétféleképpen álltak hozzá: a „,széles” vagy a „mély” stratégiát alkalmazva.

A „széles” (in-width) megközelités jogi szempontból teljességre törekvő, de másodelemzésen alapuló stratégia. Egyes minisztériumok a jogharmonizációs hatásvizsgálatot a szóban forgó politikaterület valamennyi jogszabályára el kívánták végezni.
Jogharmonizáció a környezetvédelemben. Teljességre törekvő stratégiát követett a Környezetvédelmi Minisztérium 1997-es projektje. Először összegyújtötték a hatáskörükbe tartozó több száz jogszabályt, és ezeket megfeleltették az adott politikaterület uniós jogforrásainak. Ezután összegyújtötték a megelőzó évtized valamennyi olyan alkalmazott kutatási eredményét, ami a szóban forgó szabályozási területen követett politika hatásait elemezte, és ezek, valamint a minisztérium belső szakértóivel készített interjúk alapján egy külső tanácsadó vállalkozás hatásvizsgálati tanulmányt készített. ${ }^{22}$ Mivel az eljáráshoz korlátozott összeg állt rendelkezésre, ezért meglévő több száz dokumentum másodelemzésen és államigazgatási szereplő́k megkérdezésén túlmenően nem kerülhetett sor érdekegyeztetésre, azaz arra, hogy a környezetvédelmi szabályozás alá tartozó vállalatok, önkormányzatok és más intézmények szervezetten elmondhassák álláspontjaikat a környezetvédelmi szabályozás rájuk gyakorolt hatásairól.

„Mély” (in-depth) stratégia. Más minisztériumok inkább kiválasztottak egy-egy jellegzetes, honosításra váró európai direktívát, ezek kapcsán részletes vizsgálatot készíttettek, amiból következtetéseket vontak le az érintett ágazatok jogi és intézményi környezetére. Az ilyen típusú vizsgálatok széles körú primér adatgyưjjtésen alapultak, ezért részletesebben elemezhették a harmonizációs aktus jogi, intézményi és gazdasági aspektusait. Ilyen esetekben interjú készült a szabályozó intézmények és a szabályozott vállalatok képviselőinek viszonylag széles körével is.

Az EMC direktíva hatásvizsgálata Magyarországon. A „mély” eljárást követte például 1996-ban az Ipari és Kereskedelmi Minisztérium, amikor az EU bevezetendô múszaki jellegú jogforrásai közül kiválasztott egyet, az úgynevezett EMC, azaz elektromágneses összeférhetôségi direktívát ${ }^{23}$, és ennek bevezetéséról készíttetett részletes hatásvizsgálatot egy külső tanácsadó céggel. ${ }^{24}$

Az interjúalanyokra vonatkozó mintavétel és az interjúkérdések megválasztása kritikus jelentőségú volt, ezek határozták meg a hatásvizsgálat követendô módszerét. De először az elemzendő jogszabályokból is mintát kellett venni: ebben az esetben olyan uniós direktívát igyekeztek kiválasztani, amelynek bevezetése érintette a szabályozó intézményrendszer egészét, így a szabványügyért és megfelelôségvizsgálatért felelős intézeteket, továbbá az is kritérium volt, hogy a szabályozás a vállalatok széles körére vonatkozzon. ${ }^{25}$ 
A múszaki jog uniós szabályozása az európai piac egységesítése érdekében megszüntette egy igen széles elektronikai, elektrotechnikai és múszeripari termékcsoport kötelező megfelelőségvizsgálatát. A felmérés érzékeny kérdéseket is érintett, hiszen a jogharmonizáció miatt megszúnt a megfelelőségvizsgáló intézeteknek - a szocialista országokban korábban mindenütt élvezett - jogalkalmazói szerepe. E szervezetek a felmérés időszakában még állami tulajdonban állottak, de a következő évtized folyamán sorra privatizálták azokat.

Természetesen át kellett világítani a jogszabály bevezetése által érintett elektronikai, elektrotechnikai és múszeripari termelő és szolgáltató vállalatok egy széles körét is, melyek nagy része erre az időpontra már magán- vagy vegyes tulajdonú, kicsi és közepes vállalkozásokra esett szét. Az interjúk vezérfonala minden esetben az volt, hogy a tervezett jogszabály-módosítás bemutatását követően fel kellett tárni, hogy annak hatására miként változott meg az érintett cégek múködőképessége, költségszerkezete és versenyképessége. A termékek megfelelőségvizsgálatának megváltozott jogállása a kisebb cégeket kedvezőtlenebbül, a nagyobbakat, az exportálókat és a külföldi tulajdonúakat pedig általában kedvezóbben érintette.

A minisztérium a tanulmányt ,,pilot project” jelleggel készíttette el, ami egyrészt azt jelenti, hogy a konkrét direktíva hatásai alapján más uniós jogforrások bevezetésének hatásaira is igyekeztek következtetéseket levonni, másrészt e konkrét munka módszertani tanulságai alapján más hatásvizsgálatokat is el kívántak végezni.

A hatásvizsgálatnak Magyarországon megteremtették a törvényi feltételeit, de az intézményi feltételek hiánya miatt az elfogadott törvényeket nem hajtják végre következetesen. ${ }^{26,27}$ A kormányzat 1989 óta ismételt erôfeszítéseket tesz a közigazgatás, ezen belül a szabályozási környezet modernizálására. A jogszabályok minôségét javító eszközök körében megjelent a szabályozási hatásvizsgálat is. Törvények és kormányhatározatok sora deklarálja az előzetes és az utólagos hatásvizsgálat, a jogszabály-egyszerúsítés és az érdekegyeztetés szükségességét, kötelező voltát, a szabályozási hatásvizsgálat elvégzésének módszertanát. ${ }^{28}$

Az igazságügyi tárca kezdeményezései. Az Igazságügyi Minisztérium felelős a jogszabályok minőségéért. 2002-ben az Igazságügyi Minisztériumon belül korlátozott idôtartamra létrejött egy, a hatásvizsgálatokért és a deregulációért felelős osztály, amely képzési anyagokat hozott létre ${ }^{29}$, és kísérleti (,pilot project”) jelleggel konkrét jogszabályok hatásvizsgálatát végezte el. ${ }^{30}$
A gazdasági tárca kezdeményezései. A magyar kormányzat kis- és középvállalkozás-fejlesztési programjának céljai között kitüntetett helyet foglal el a stabil, átlátható, kiszámítható múködési feltételek biztosítása, az adó- és adminisztrációs terhek folyamatos csökkentése. ${ }^{31}$ Magyarország az uniós csatlakozásra váró többi országgal közösen 2002 áprilisában aláírta az „Európai Charta kisvállalatok részére" címú dokumentumot, amivel kötelezettséget vállalt arra, hogy a kisvállalkozások igényeinek figyelembevételével alakítja a hazai KKV-fejlesztés politikáját és programját. ${ }^{32}$ Ezzel hivatalosan elfogadottá vált az alábbi alapelv: a KKV-k jogi és szabályozási környezetét úgy kell alakítani, hogy a kormányzat és a vállalkozások viszonyában tartósan alacsony szintre csökkenjenek a tranzakciós költségek ${ }^{33}$. A tranzakciós költségek egyben a szabályozási hatásvizsgálatok központi indikátorai. A KKV-kat is érintő jogszabály-módosítások hatásvizsgálatának elvégzését kötelezôvé tette a kis- és középvállalkozásokról szóló törvény is. ${ }^{34}$

Konzultáció. Magyarországon a vállalkozói érdekcsoportokkal való egyeztetés a jogalkotási folyamat szerves részének tekinthető, de az egyeztetések konkrét megvalósítása változó minôségú. Az országos gazdasági kamarák egyik - törvényben is rögzített - feladata, hogy véleményezzék a gazdasági tárgyú előterjesztések és jogszabályok tervezeteit. ${ }^{35}$ Ennek keretében 2003ban a minisztériumok 250 anyagot küldtek a Magyar Kereskedelmi és Iparkamarához véleményezésre. ${ }^{36}$ A Kamara által alapított gazdaságelemző intézet évente többször fordul kérdőíves kutatás keretében a vállalkozókhoz, hogy begyújtse az üzleti helyzetról és az adminisztratív környezet aktuális változásairól alkotott véleményeket. ${ }^{37}$ A konzultációt szolgálják egyes online vitafórumok is, így például a vállalkozóknak a szabályozással kapcsolatos véleményeit szervezetten gyújtő weboldalt múködtetett 2006-2007-ben a Gazdasági és Közlekedési Minisztérium. ${ }^{38}$

A dereguláció eredetileg azt jelenti, hogy hatályon kívül helyezik az életviszonyok változása folytán feleslegessé váló jogszabályokat. ${ }^{39} 1989$ és 1991 között, valamint 1995 és 1998 között kiterjedt deregulációs projektek keretében jogszabályok ezreit helyezték hatályon kívül: az Igazságügyi Minisztérium adatai szerint 1990 óta legalább hétezer törvény, törvényerejú rendelet és miniszteri rendelet vesztette hatályát. Deregulációs program van érvényben, mely szerint a minisztériumoknak és a helyi önkormányzatoknak ki kell alakítaniuk, és rendszeresen aktualizálniuk kell a dereguláció és a jogszabály-elókészítés során végzett hatásvizsgálati tevékenység tárcán belüli szervezeti és eljárási rendjét. ${ }^{40} \mathrm{~A}$ gyakorlatban azonban a hatályos magyar jogszabályok száma 1990 és 2004 között 
megduplázódott, ahol a növekménynek mintegy fele a létezó joganyag módosítására vonatkozik. A módosításra sok esetben azért van szükség, mert átgondolatlanul hozták meg a jogszabályokat, azokat nem alapozták meg hatásvizsgálatokkal.

Összegzésként megállapítható, hogy Magyarországon a hatásvizsgálati tevékenység kodifikáltsága megfelelő, de a megvalósító intézmények krónikus erőforráshiányra hivatkozva csak eseti jelleggel tartják be az ide vonatkozó előírásokat. A vállalkozásokat érintő jogszabályokat alacsony intézményesítettségi szinten és kevéssé szervezetten vetik alá hatásvizsgálatnak. A különböző tárcáknál megvalósult, egymástól elszigetelt hatásvizsgálati projektek külön-külön előremutató kezdeményezések, de együttesen sem érték el azt a kritikus tömeget, aminek már számottevő hatása lehetett volna a vállalkozások szabályozási környezetére, nemhogy annak reformjára. A minisztériumok ügyrendje nem rendelkezik a szabályozási hatásvizsgálatok elvégzésérôl, és amelyik tárcánál ilyen tevékenység eseti jelleggel mégis folyik, ott ez nincs összehangolva a hatásvizsgálat hagyományos és bevált módjával, melynek során a vállalkozói érdekcsoportokkal, érdekképviseletekkel konzultálnak. Erôteljes politikai akaratra és hosszabb távú szemléletre lenne szükség ahhoz, hogy a hatásvizsgálati kultúra elterjedjen a magyar közigazgatásban.

\section{A bürokráciacsökkentő jogszabályok és azok végrehajtó intézményei az Egyesültt Államokban}

Az Amerikai Egyesült Államokban az 1980-ban elfogadott ún. bürokráciacsökkentô törvény (Paperwork Reduction Act) alapján valamennyi szövetségi hivatalnak engedélyt kell kérnie egy központi kormányhivataltól (Office of Management and Budget, OMB), ha adatokat akar gyưjiteni a vállalkozásoktól vagy a háztartásoktól..$^{41}$ Ezeket az engedélyeket csak akkor kapják meg, ha az adatgyújitésról bizonyítható, hogy az szükséges, és nem terheli meg túlságosan az érintetteket. E törvény alapján az elmúlt negyedszázadban a szövetségi hivatalok információgyújtési tevékenységének korlátozására éves terveket állítottak össze. Ezek a bürokráciacsökkenési tervek hatásvizsgálatokon alapulnak, melyek becslést adnak a vállalkozások és háztartások által a szabálykövetésre fordított órák számára. A kormányhivatalok kötelesek ezt a jelzőszámot évente előre megadott mértékben csökkenteni.

Az Office of Management and Budget (OMB) nevú szövetségi kormányszerv feladata, hogy áttekintse a törvénytervezeteket, mielőtt azok hatályba lépnek. ${ }^{42}$ Ennek az ellenőrzésnek jogszabályba foglalt, hatásvizsgálat jellegú módszertana van, melyet 1993 óta a szövetségi kormánynak a szabályozási tervezésról szóló 12866. számú rendelete rögzít. ${ }^{43} \mathrm{Ez}$ az USA legfontosabb hatásvizsgálati jogszabálya, mely arra kötelezi a szövetségi kormányhivatalokat, hogy ne csak jogszabályok, hanem bármely javasolt intézkedés esetén végezzenek gazdasági elemzést a várható hatásokról, legyenek azok gazdasági, környezetvédelmi, közegészségügyi, biztonsági vagy újraelosztási jellegúek, akár a nemzeti jövedelemre, akár a nemzeti vagyonra vonatkoznak.

A fenti két jogszabályt kiegészíti a szabályozások rugalmasságára vonatkozó törvény, amely kiemelten kezeli a kisvállalkozások azon igényét, hogy vegyék figyelembe szempontjaikat a döntéshozatal során. ${ }^{44}$

Vizsgáljuk meg közelebbról a 12866. számú „Regulatory Planning and Review” rendeletben rögzített hatásvizsgálati módszertant. Minden hatásvizsgálat gazdasági elemzésen alapul, mely három összetevőbool áll.

(A) Annak igazolása, hogy a javasolt intézkedésre szükség van. Jogszabályra csak akkor van szükség, ha fennáll a piaci mechanizmusok valamelyik kudarca. Ilyen lehet a természetes monopólium, a piaci túlsúly, a fogyasztó elégtelen információja, valamint a jelentós externáliák ${ }^{45}$. De még ha ezek a feltételek fenn is állnak, az USA-ban akkor is különösen erôs indoklást igényelnek az olyan intézkedések, mint az árszabályozás, a termelési vagy értékesítési kvóták, a kötelezô minôségi standardok és a belépési korlátok.

(B) Az alternatív megközelítések, egyéb szabályozási vagy szabályozáson kívüli megoldások elemzése. Szövetségi szabályozásra csak akkor van szükség, ha alternatív módon nem lehet a problémát megoldani. Ilyen alternatíva lehet a bírósági út és a különbözó szubvenciók. Azok a szabályozások számítanak sikeresnek, amelyek mérnöki szabványok helyett eredményszintek elérését követelik meg az egészségügyi, biztonsági és környezetvédelmi szabályozók által szabályozottaktól. Továbbá a szegmentált szabályozást kedveli az amerikai kormányzat, ami azt jelenti, hogy különbözó népességi vagy vállalkozói rétegekre más és más jellegú követelményeket célszerú megfogalmazni.

(C) A költségek és hasznok elemzése. A költségeket és hasznokat valamennyi alternatíva esetén azzal az alapforgatókönyvvel kell összehasonlítani, hogy a szóban forgó szabályozást egyáltalán nem hozzák meg. Ahol csak lehet, minden költséget és hasznot pénzben kell kifejezni, de ahol ez nem lehetséges, ott tartózkodni kell a mesterkélt megoldásoktól. A pénzügyileg kifejezhetô hosszabb távú hatásokat diszkontálni kell, azaz ki kell számítani jelenértéküket. Ahol a különböző következmények kimenetelei bizonyos valószínúséggel következnek csak be, ott kockázat- és bizonytalanság- 
elemzést kell végezni. A kockázat abban különbözik a bizonytalanságtól, hogy míg kockázat esetén a kimenetelek valószínúségeloszlása ismert, bizonytalanság esetén inkább arról van szó, hogy ezek a valószínúségek nem ismertek. Bizonytalanság származhat adathiányból, tudományos ismeretek hiányából vagy bizonyos jelenségek alapvető megjósolhatatlanságából. A rendelet a szabályozások hatásait övezó bizonytalanságot úgy kívánja csökkenteni, hogy elôírja: a kockázatra, hasznokra és költségekre vonatkozó információkat mindenki számára áttekinthetően kell kezelni.

A rendelet az alábbi kvantitatív módszereket támogatja: szimuláció, érzékenységvizsgálat ${ }^{46}$, Delphimódszerek $^{47}$ és metaanalízis ${ }^{48}$. A gazdasági elemzések rejtett feltételezéseit, kiindulópontjait fel kell tárni, és ahol alternatív kiindulópontok is feltételezhetók, ott érzékenységvizsgálatot is kell végezni ezen alternatív kiindulópontok feltételezésével. Ki kell mutatni az úgynevezett disztribúciós hatásokat is, hiszen egy jogszabály hatásai nem egyenletesen jelentkeznek az egész lakosságban, hanem jövedelmi rétegek, faji hovatartozás, nemi vagy ipari szektorhoz történő tartozás szerint változnak. Az idôbeli hatásokat is figyelemmel kell kísérni, hiszen ami az egyik nemzedék számára kedvezô hatás, az a következó nemzedéket már károsíthatja.

A hasznok értékelése különösen komplex, és amikor a hasznok az egészséget és a biztonságot érintik, az pénzügyileg már nem kifejezhető. Az olyan jogszabályok esetében, amelynek haszna az általuk évente átlagosan megmentett emberéletek számával fejezhetô ki, nem feltétlenül kell pénzben kifejezhetô haszonra törekedni.

A költségek viszont sokkal könnyebben megfogalmazhatók pénzügyi fogalmakkal: ilyenek a magánszektor szabálykövetési költségei és a kormányzat adminisztratív költségei. Minden költséget ahhoz viszonyítva kell kiszámítani, mintha a szabályozást nem valósították volna meg, de a többi feltétel teljesen azonos lenne. Nehéz különbséget tenni a valóban felmerülő költségek és a transzferköltségek között. Az utóbbiak inkább csak a vagyon újraelosztását jelentik a jogszabály hatására. Ilyenek például a biztosítási költségek, amelyek nem csökkentik egy baleset társadalmi költségeit, csak tovább terhelik azokat a biztosítókra. Ezek nem tartoznak bele a jogszabálynak sem a költségeibe, sem a hasznaiba, viszont a redisztributív hatásait jól jellemezhetik. Hasonlóképpen azok a szabálykövetési költségek, amelyek adókkal terheltek - például ha valamely jogszabály következtében kötelezó megvásárolni egy berendezést - akkor az adót nem kell beleszámítani a költségbe, mert az nem társadalmi szinten jelentkező költség, hanem csak egyfajta redisztribúció a vásárló és az állam között.
Az idézett jogszabályokban foglalt elơírások csupán a szövetségi állam önkorlátozásának tekinthető́k. Az autonómia magas foka miatt a törvénybe foglalt elvek a tagállami és a helyi szintre vonatkozóan csupán módszertani ajánlásként értelmezhető́k. Ezen túlmenóen azonban az USA több tagállama is múködtet szabályozási hatásvizsgálati rendszereket. ${ }^{49}$

Az Amerikai Egyesült Államok szövetségi kormányának kisvállalkozás-fejlesztési hivatala, a „Small Business Administration” 1976-ban létrehozta „Office of Advocacy” nevú részlegét, melynek feladata, hogy független, de érdekképviseleti jelleggel csökkentse a szövetségi törvényhozás és szabályozás intézkedései által a kisvállalkozásokra gyakorolt kedvezőtlen hatásokat. Ez a részleg nemcsak hatásvizsgálati kutatásokat végez, hanem tanácsadási szekciót is múködtet, és aktívan lobbizik a törvényhozásban és a kormányhivatalok körében. 2007-ben a Small Business Administrationnak az USA területén tíz regionális központban múködik helyi képviselete, és ezekben a kormányhivatalokban függetlenített jogkörrel dolgoznak az „Office of Advocacy” képviselői, a „Regional Advocate”-ok.

Amerikábanajogszabályalkotás minőségétnemcsak kormányszervek, hanem nagyobb nemkormányzati szervezetek, közpolitikai kutatóintézetek, vagy más szóval „think-tank”-ek is értékelik. A ,think-tank”ek függetlenségét az biztosítja, hogy nem fogadnak el kormányzati szervezetektól támogatást. A hatásvizsgálatokat megalapozó közgazdasági elemzés minőségét javítja, hogy versengố elemzési eredmények látnak napvilágot. Míg tehát az Amerikai Egyesült Államokban az egyetemek és a tanácsadó cégek tömegei foglalkoznak hatásvizsgálattal és a meglévő hatásvizsgálatok minôségének elemzésével, addig Európában ennek még sokkal kevésbé alakult ki az intézményi háttere.

\section{Az USA szövetségi szabályozásainak hatása az amerikai kisvállalkozásokra}

A szabályozásoknak az amerikai kisvállalkozásokra gyakorolt költséghatásait ma már pontosan ki lehet mutatni. A ,Small Business Administration Office of Advocacy" 2005-ben felmérést végeztetett a szövetségi szabályozások költséghatásairól, ezen belül az olyan költségekról, amelyek a kis- és középvállalkozásoknál merülnek fel. ${ }^{50} \mathrm{~A}$ jelentés négy nagy kategóriába bontja a szövetségi szabályozást: gazdasági, munkaügyi, környezeti és adóügyi szabályozásra. A gazdasági szabályozás bel- és külföldi szabályozásra bomlik fel. Az adóügyi szabályozás felmért költségei nem tartalmazzák magukat az adókat, hanem tisztán az adózás adminisztrációjának költségeit. A jelentés a kisvállalkozá- 
sokat úgy definiálja, mint amelyek 20 alkalmazottnál kevesebbet foglalkoztatnak: az USA-ban a cégek $90 \%$-a ilyen.

A jelentés az alábbi öt szektorra bontja az amerikai gazdaságot: feldolgozóipar, kis- és nagykereskedelem, szolgáltatások, egészségügy és egyéb.

A szövetségi jogszabályoknak tulajdonítható direkt költségek két részre bomlanak: egyrészt azokra a költségekre, amelyek kormányzati hivataloknál merülnek fel, másrészt a magánszektor vállalkozásainál felmerülő költségekre. A jelentés csak az utóbbiakra tér ki. Például egy környezetvédelmi rendelkezés esetében a jelentés nem tér ki a rendelkezés betartatásának költségeire, tehát azokra, amelyek a végrehajtó hatóságnál jelentkeznek, hanem csak a vállalkozásoknak azon környezetvédelmi beruházásaira, papírmunkáira és szakértői kiadásaira, amelyek a jogszabály által kikényszerített környezetvédelmi többlettevékenységek. Tapasztalati adatok azt mutatják, hogy a hatóságok kiadásai körülbelül a húsz-huszonötöd részét teszik ki a vállalkozások kapcsolódó kiadásainak.

A jelentés nem tér ki a tagállami és a települési szintú szabályozások költséghatásaira. Ugyanakkor felöleli azokat a kiadásokat, amelyeket egyéneknek azért kell meghozniuk, mert többet kényszerülnek fizetni egy szövetségi jogszabály hatására, amikor a vállalkozásoknak sikerül a többletköltséget továbbhárítani fogyasztóik felé.

Eredmények. A kutatás fố számszerú eredménye, hogy a szövetségi jogszabályok által a KKV-kra gyakorolt szabálykövetési költséghatás összesen meghaladja az évi egytrillió dollárt, azaz a nemzeti jövedelem több mint egytizedét. Az egy alkalmazottra jutó költségek érzékenyek a vállalatnagyságra. Például a feldolgozóiparban a közepes és nagy cégeknél az egy alkalmazottra jutó szabálykövetési költségek fele akkorák, mint ugyanezek a költségek a kis cégeknél (1. táblázat).

1. táblázat

Az USA kicsi és közepes cégei számára a szövetségi szabályozás által okozott költségek becsült értéke Amerikai Egyesült Államok, 2004

\begin{tabular}{|l|c|}
\hline & Milliárd USD \\
\hline Gazdasági & 591 \\
\hline Munkaügyi & 106 \\
\hline Környezetvédelmi & 221 \\
\hline Adóügyi & 195 \\
\hline Összes szövetségi szabályozás & 1.113 \\
\hline
\end{tabular}

Forrás: Crain, W. M. (2005): The Impact of Regulatory Costs on Small Firms, Lafayette College, Easton, Pennsylvania, p. 29.
A legsúlyosabb költségeket a környezetvédelmi és az adózási szabályok generálják. A környezetvédelmi szabályozás magasabb fajlagos költségeket ró a kisebb vállalkozásokra, mint a nagyokra. Ugyanakkor a gazdasági jogszabályok a nagyobb vállalkozásokat sújtják jobban. A munkaügyi szabályozások viszont a középnagyságú cégeket terhelik a legsúlyosabban: ennek az az oka, hogy a kisvállalkozások sok esetben felmentést kapnak a munkaügyi jogszabályok egy része alól.

Vizsgáljuk meg letesebben is az 1. táblázatban felsorolt és értékelt szabályozási területeket.

- Gazdasági szabályozás. A gazdasági szabályozók korlátozzák és ösztönzik a piachoz való hozzáférést, egyes inputok vagy termelési módszerek használatát, az outputok megválasztását, az árak meghatározását és a nemzetközi kereskedelemben, valamint a befektetésben való részvételt. Ide tartoznak a kvótákról és a vámokról szóló, a versenyt korlátozó, az árakra vonatkozó, a termelést és a foglalkoztatást korlátozó szabályozók.

- Munkaügyi jogszabályok. Ide tartoznak a fizetésekkel, juttatásokkal, a munkabiztonsággal és munka-egészségüggyel, valamint a munkahelyeken érvényes, az emberi jogokkal kapcsolatos jogszabályok. A tanulmány 25 különböző törvényre és rendelkezésre tér ki, amelyek lefedik az USA 2000-ben érvényes munkahelyi szabályozásának túlnyomó részét. A kisvállalkozás-kutatás számára figyelemre méltó körülmény, hogy a 25 fontos munkaügyi jogszabály közül 6 kivételt tesz a 20nál kevesebb alkalmazottat foglalkoztató vállalkozásokkal. Ilyen például az „Age Discrimination in Employment Act", amely a kor szerinti diszkriminációt tiltja, valamint az „Americans with Disabilities Act”, amely a fogyatékkal élő amerikaiak elleni diszkriminációt tiltja: ezek olyan jogszabályok, amelyeknek bizonyos rendelkezései nem vonatkoznak a 20-nál kevesebb alkalmazottat foglalkoztató cégekre.

- Környezetvédelmi rendelkezések. A környezetvédelmi szabályozások költséghatásait onnan ismerjük, hogy az Amerikai Egyesült Államok Környezetvédelmi Hatósága (U.S. Environmental Protection Agency) valamennyi lényeges, 2004 előtt kibocsátott környezetvédelmi jogszabályhoz környezeti hatásvizsgálatot készíttetett.

- Adóügyi jogszabályok. A tanulmányban szereplő dollár értékek nem az adó mértékét mutatják, hanem a szövetségi adóügyi adminisztráció által kibocsátott úrlapok kitöltésének idővonzatára vonatkoznak. Reális órabérekkel számolva pénzben 
fejezik ki azt, hogy egy átlagos vállalkozásnak mennyi idóbe telik az adatokat összeszedni és az úrlapokat kitölteni. A számítások kitérnek a vállalati nyereségadók, a társadalombiztosítá-sok és a szövetségi személyi jövedelemadók kitöltésének időigényére.

\section{Lábjegyzet}

${ }^{1}$ Értékes megjegyzéseiért köszönetet mondok dr. Szirmai Péter igazgató úrnak (Budapesti Corvinus Egyetem, Vállalkozásfejlesztési Intézet).

${ }^{2}$ Futó Péter (1999): Kis- és középvállalkozási politika az EU-tagállamokban és régiókban. Európai Tükör, 1. sz. p. 77-89.

${ }_{3}^{3}$ Better Regulation for Growth and Jobs in the European Union. Az Európai Unió Bizottságának közleménye, 2005.

${ }^{4}$ Például a KKV-k esetében: European Commission (2006): European Charter for Small Enterprises - 2006 good practice selection. Luxembourg: Office for Official Publications of the European Communities.

5 European Governance-a White Paper. Commission of The European Communities. Brussels, 25.7.2001. COM(2001) 428 final.

${ }^{6}$ Futó Péter (1998): Az Európai Unió kis- és középvállalkozási szektorának helyzete és a közösségi KKV-politika. Európai Tükör, december, p. 18-39.

7 The European Commission's Business Impact Assessment System. Megjelent: az Improving the Quality of Legislation for Business sorozat részeként. Brussels, 1997. Directorate General XXII, p. 579.

${ }^{8}$ Regulatory Impact Analysis: Improving the Quality of EU Regulatory Activity. Készítette: The European Policy Center. 2001. szeptember.

${ }^{9}$ Commission of the European Communities (2002): Communication from the Comission on Impact Assessment. $\operatorname{COM(2002)} 276$ final, Brüsszel, május 6., 19 oldal. Továbbá: Enterprise Directorate-General, European Commission (2002): Business impact assessment pilot project -Final report - Lessons learned and the way forward, Enterprise Papers, No 9., 2002, 27 oldal

${ }^{10}$ Radaelli, C. M. (2003): Getting to Grips with the Notion of Quality in the Diffusion of Regulatory Impact Assessment in Europe. Paper Prepared for the Conference on Regulatory Impact Assessment. Manchester, UK, 26 and 27 November.

11 Australian Guide to Regulatory Performance Indicators (1999)

12 Advancing regulatory reform in Europe - A joint statement of the Irish, Dutch, Luxembourg, UK, Austrian and Finnish Presidencies of the European Union. 7 December 2004, 11 oldal.

13 Az EU Bizottságának IP/06/1562 szmú sajtóközleménye, Brüszszel, 2006. november 14.

${ }^{14}$ Renda, Andrea (2006): Impact Assessment in the EU: the State of the Art and the Art of the State. AmCham EU, március, Brüszszel, 18 oldal.

${ }^{15} \mathrm{Az}$ illetékes brit kormányhivatal, a „Better Regulation Executive” weboldaláról letölthető a RIA javasolt módszertana: http://www.cabinetoffice.gov.uk/regulation/ria/ria_guidance/index.asp

${ }^{16}$ U.K. Better Regulation Team Small Business Service (2005): Small Firms Impact Test Guidance For Policy Makers. London. 7 oldal.
17 Bourn, John (2006): Evaluation of Regulatory Impact Assessments 2005-06. National Audit Office, London, 43 oldal

18 A Comparative Analysis of Regulatory Impact Assessment in Ten EU Countries. A Report Prepared for the EU Directors of Better Regulation Group. Dublin, May 2004. Italian, Irish and Dutch Presidencies of the Council of the European Union, 199 oldal

19 Veit, Sylvia (2005): Entpolitisierung staatlicher Regulierungsprozesse durch Gesetzesfolgenabschätzungen? FoJuS Diskussionspapiere, Nr. 3. 23 oldal.

${ }^{20}$ Gemeinsame Geschäftsordnung der Bundesministerien (GGO), ismerteti Veit idézett cikke.

${ }^{21}$ Red Tape for Business in Sweden. Regulation Indicator for 2006. Board of Swedish Industry and Commerce for Better Regulation (NNR) August 2006, Stockholm, 32 oldal.

${ }^{22}$ Futó Péter (1998): Jogharmonizáció a környezetvédelemben. Európai Tükör, 3. sz. p. 31-45.

${ }^{23} \mathrm{Az}$ elektromágneses összeférhetőség (EMC) követelmény, melynek célja a berendezések és azok üzemi környezete közötti elektromágneses zavaró hatások megszüntetése, Átfogó szabályozását az alábbi EU-irányelv biztosítja: Council Directive 89/336/EEC of 3 May 1989 on the approximation of the laws of the Member States relating to electromagnetic compatibility (EMC Directive).

${ }^{24}$ Futó Péter - Bonifert Donát - Parajdi Eszter - Binning, Kenneth (1996): Az elektromágneses összeférhetőségre vonatkozó jogszabályok EU-harmonizációjának hatása az elektronikai, elektrotechnikai és múszeripari vállalatokra. Kézirat, 108 oldal. Ipargazdasági Kutató és Tanácsadó Kft., Budapest. A kutatást támogatta a Know How Fund (Egyesült Királyság).

${ }^{25}$ Binning, Kenneth - Futó Péter (1997): A jogharmonizációs szabályozás gazdasági hatásvizsgálata. Statisztikai Szemle, 2. sz. p. 101-114.

${ }^{26}$ Orbán Krisztián - Kovácsy Zsombor (2005): Recent Regulatory Reform Activities in Hungary. Kézirat, Igazságügyi Minisztérium, Budapest.

27 OECD (2005): Regulatory Impact Analysis in OECD Countries. Challenges for developing countries. Szerk.: Delia Rodrigo, OECD kiadvány, 33 oldal, Dhaka, Bangladesh.

${ }^{28}$ A jogalkotásról szóló 1987. évi XI. törvény, valamint az 1994. évi 1008. sz. kormányhatározat (szeptember 20.) és az 1999. évi 1052. sz. kormányrendelet és a 2005. évi 1082. sz. kormányrendelet (július 27.), 8001/2006 (január 30) IM-tájékoztató.

${ }^{29}$ Kovácsy Zsombor - Orbán Krisztián (2004): A szabályozás hatásvizsgálata. Módszertani útmutató. A „Társadalmi hatások vizsgálata” c. fejezetet írta: Pavel Ovseiko. Megjelent a BM Közigazgatásszervezési és Közszolgálati Hivatalának gondozásában, a „Módszertani Füzetek” sorozat keretében. Budapest.

${ }^{30}$ Példa konkrét hatásvizsgálatra: Az üvegházhatású gázok kibocsátási egységeinek kereskedelmérôl szóló törvényjavaslat előzetes hatásvizsgálata. Feiler József, Kelemen Ágnes, dr. Kiss Rita, dr. Kovácsy Zsombor, Orbán Krisztián. Budapest, GKMIM-KVVM, 2004. november, kézirat, 40 oldal.

${ }^{31}$ Széchenyi Vállalkozásfejlesztési Program. Kihirdetve: 1213/ 2002. (XII. 23.) Korm. határozat.

32 Gazdasági és Közlekedési Minisztérium (2006): A kis- és középvállalkozások fejlesztésének koncepciója 2007-2013. Tervezet. Kézirat, Budapest.

${ }^{33}$ Kállay László - Kissné Kovács Eszter - Kőhhegyi Kálmán (2003): Piaci környezet, szabályozás és vállalkozásösztönzés. A „Gazdasági versenyképesség: helyzetkép és az állami beavatkozás lehetôségei” címú kutatás résztanulmánya. Kézirat, Budapest.

\section{VEZETÉSTUDOMÁNY}


34 KKV Törvény: 2004. évi XXXIV. törvény 11. §-a

35 A gazdasági kamarákról szóló 1999. évi CXXI. törvény 12. § (1) bekezdés a) pontja alapján.

${ }^{36} \mathrm{Az}$ „Európai Charta kisvállalkozások részére” címú uniós határozat 2004. évi végrehajtási jelentése. A magyar kormány jelentése letölthető az alábbi weboldalról: http://ec.europa.eu/enterprise/enterprise_policy/charter/2005_charter_docs/report_hungary_2004_hu.pdf

37 KKV Körkép - 2006. április. A Figyelő, a Magyar Kereskedelmi és Iparkamara Gazdaság- és Vállalkozáselemző Intézete és a Volksbank közös kutatása. Kérdôív és kutatási jelentés a http:// www.gvi.hu weboldalon.

38 „Üzletre hangolva” - Program a vállalkozói környezet dinamizálásáért. Interaktív weboldal szabályozási javaslatok gyújtésére az alábbi témákban: 1 . A cég- és adóadminisztráció egyszerúsítése. 2. Vállalkozások jogbiztonságának növelése. 3. Pénzügyi múködési feltételek javítása. 4. Verseny tisztaságának, átláthatóságának biztosítása. 5. Vállalatirányítás (corporate governance). 6. Korábbi pontokban nem szereplő, szakmaspecifikus javaslatok. 2006-2007-ben a weboldal elérhetô a www.gkm.gov.hu portálon.

${ }^{39}$ Újabban a „dereguláció” kifejezés „liberalizáció”, „enyhítés” értelemben is használatos. (Ld. pl a Wikipedia c. internetes lexikonban, vagy a Magyar Virtuális Enciklopédia (http://www.enc. hu/) címszavait).

${ }^{40}$ A jogszabályok deregulációs felülvizsgálatáról szól a 2358/2002. (XI. 28.) és a 1046/2003. (V. 28.) kormányhatározat.

${ }^{41}$ Paperwork Reduction Act of 1980, Pub. L. No. 96-511, 94 Stat. 2812 (Dec. 11, 1980).

${ }^{42}$ Lutter, Randall (2001): Study on Economic Analysis of Regulation in the U.S. (What Lessons for the European Commission?) - Report to the Enterprise Directorate General, European Commission for the Workshop on Impact Assessment in Member States. AEI-Brookings Joint Center for Regulatory Studies, Brüsszel.

43 Executive Order 12866 of September 30, 1993, „Regulatory Planning and Review".

44 Regulatory Flexibility Act of 1980. Módosítva az 1996-ban elfogadott „Small Business Regulatory Enforcement Fairness Act" által.

45 Egy piaci adásvétel esetében az adott ügyleten kívülálló szereplő(k) környezetét befolyásoló, nem szándékolt hatásokat külső gazdasági hatásnak, externáliának nevezzük.

46 Ennek során egy adott modell jóságát úgy vizsgálják, hogy szisztematikusan változtatgatják annak bemeneti paramétereit és figyelik a kimenetelre való hatást.

47 A Delphi-módszer alkalmazása során egymással személyesen nem találkozó szakértốk egy csoportját először arra kérik, hogy válaszoljanak egy kérdésre. A második hullámban ugyanarra a kérdésre kell válaszolni, de most már az elsố hullám összesített eredményeinek ismeretében.
48 A metaanalízis olyan másodelemzés, melyben több, korábban elvégzett felmérés és tanulmány adatait összegzik egy kutatási hipotézis megvizsgálása céljából.

49 Például New York állam 1995 óta folyamatosan tartó szabályozási reformjáért a kormányzó hivatalának alábbi ügyosztálya felelôs: Governor's Office of Regulatory Reform (GORR) Ld: http://www.gorr.state.ny.us/

${ }^{50}$ Crain, W. Mark (2005): The Impact of Regulatory Costs on Small Firms, Lafayette College, Easton, Pennsylvania

\section{Felhasznált irodalom}

Binning, Kenneth - Futó P. (1997): A jogharmonizációs szabályozás gazdasági hatásvizsgálata. Statisztikai Szemle, 2. sz. p. 101-114.

Bourn, J. (2006): Evaluation of Regulatory Impact Assessments 2005-06. National Audit Office, London

Európai Unió (1997): The European Commission's Business Impact Assessment System. Megjelent: az Improving the Quality of Legislation for Business sorozat részeként. Brussels,. Directorate General XXII, p. 579.

Európai Unió (2004): A Comparative Analysis of Regulatory Impact Assessment in Ten EU Countries. A Report Prepared for the EU Directors of Better Regulation Group. Dublin, May. Italian, Irish and Dutch Presidencies of the Council of the European Union

Futó P. (1998): Az Európai Unió kis- és középvállalkozási szektorának helyzete és a közösségi KKV-politika. Európai Tükör, december p. 18-39.

Futó P. (1998): Jogharmonizáció a környezetvédelemben. Európai Tükör, 3. sz. p. 31-45.

Futó P. (1999): Kis- és középvállalkozási politika az EUtagállamokban és régiókban. Európai Tükör, 1. sz. p. 77-89.

Kovácsy Zs. - Orbán K. (2004): A szabályozás hatásvizsgálata. Módszertani útmutató. A Társadalmi hatások vizsgálata c. fejezetet írta: Pavel Ovseiko. Megjelent a BM Közigazgatásszervezési és Közszolgálati Hivatalának gondozásában, a Módszertani Füzetek sorozat keretében. Budapest

OECD (2005): Regulatory Impact Analysis in OECD Countries. Challenges for developing countries. Szerk.: Delia Rodrigo, OECD-kiadvány, június, Dhaka, Bangladesh

Cikk beérkezett: 2007. 12. hó

Lektori vélemény alapján átdolgozva: 2008. 2. hó 